\title{
Analysis on the Construction of Financial Computerizing and Fintech Management
}

Yanli Xi*

School of Finance, Central University of Finance and Economics, Beijing 100081, China. E-mail: 1580868858@qq.com

Abstract: With the continuous development of China's economy, the development of financial industry is getting faster and faster. The construction of financial computerizing is an inevitable trend of financial development, arousing widespread concern from society. This article explores and analyzes the effective development strategies of constructing financial computerizing and fintech management, aiming to provide some experience and reference for the development of financial computerizing in China.

Keywords: Construction of Financial Computerizing; Fintech Management; Exploring and Analyzing; Experience and Reference

\section{Introduction}

Information technology has been widely applied in the banking industry with the rapid development of world economic and financial integration, and some achievements have been made in the overall informationization level of banks in China. However, there are still some gaps in the terms of financial computerizing between Chinese and international banks. At present, the construction of financial computerizing in commercial banks has gradually entered the rapid development stage of overall planning and organic integration from the original small scale, which will be of great significance to the overall strength of China's banks and the formation of competitive pattern.

\section{The relationship between construction of financial computerizing and fintech management}

The construction of financial computerizing is the basic content and foundation of fintech management. That is to say, the construction of financial computerizing under standardized management and unification can provide an important guarantee for the development of fintech management. However, no matter how advanced the construction project of financial computerizing is, there will be defects and problems in the construction process, and the completed system cannot run normally and safely, if attention is only paid to the construction of financial computerizing, but not to the unified and standard construction management. Only by doing a good job in the construction and management of financial computerizing can a solid foundation be laid for the effective management of financial technology.

\section{Main problems in the construction of financial computerizing in China}

Copyright (C) 2020 Yanli Xi

doi: $10.18282 / \mathrm{ff}$. v9i4.1542

This is an open-access article distributed under the terms of the Creative Commons Attribution Non-Commercial License

(http://creativecommons.org/licenses/by-nc/4.0/), which permits unrestricted non-commercial use, distribution, and reproduction in any medium, provided the original work is properly cited. 


\subsection{The lack of standard construction system making it unable to achieve systematic develop- ment}

Although some achievements have been made in the construction of financial computerizing in China, there is a lack of a perfect management and some defects in specialization, systematicness and practical experience, because it is formed in a non-standard environment. This leads to the failure of the system in processing large-scale transactions. As there is no proper cooperation of financial computerizing in terms of system development, and a set of perfect financial business processing modes and information format standards have not been formed, it is impossible to realize data sharing and effective information dissemination among various systems. Furthermore, this disorderly construction mode may bring about difficulties in information exchange between branch banks in different regions, hindering systematic development of the construction of financial computerizing ${ }^{[1]}$.

\subsection{Incompatibility between financial talents and reality}

Information technology is widely used in banking business along with the former's continuous development. The effective application of information technology has brought about many electronic financial products, technical subjects and financial products. As the financial market is constantly expanding, the financial industry has also developed rapidly. Therefore, the construction of financial computerization during the rapid development of the financial industry calls for more financial talents with higher professional and technical skills. However, the discipline construction of financial specialty in China is not good enough to meet the requirements, leading to the incompatibility between the training of talents and social development. To be specific, college students majored in finance have learnt more theoretical knowledge, with insufficient practical operation ability, which to some extent affects the development of financial computerizing.

\subsection{Problems in the supervision of financial computerizing business}

While the financial computerizing business is becoming more and more common in China, and the financial business of various banks is quite frequent, there is a lack of corresponding supervision and management mechanism, resulting in insufficient or none supervision of financial business, and bringing out many loopholes. Moreover, the lack of financial business-related industry standards and professional regulations in China leads to the lack of laws and regulations on the supervision of financial computerizing business, to a great extent hindering the benign development of the construction of financial computerizing.

\section{Effective strategies to improve the construction level of financial com- puterizing and fintech management}

The level of science and technology is an important factor in the development of banking industry. Financial computerizing is a long-term systematic project that can't be done in a short period of time or once and for all. The ultimate influence factor of financial technology is management. That is to say, the future development trend of the banking industry is to accelerate scientific and technological innovation by scientific management, and scientific and technological management is essentially the management of people ${ }^{[2]}$.

\subsection{To formulate the overall planning of science and technology development, and clear de- velopment direction}

As the development of science and technology is ever-changing, it is necessary for the banking industry to effectively adjust its development rules according to the current situation of technology development. While the development of science and technology is unstable, the banking industry must apply the continuity of science and technology and determine its stability in order to adapt to the changeable development of social science and technology. Therefore, the bank management should formulate the staged development goals and the overall framework of the bank's scientific and technological development, and gradually unify the ideology of bank managers and staff. 


\subsection{To build a strong scientific and technological team}

The relevant experience of international banks has proved that China's financial industry should pay attention to cultivating its own scientific and technological team. A strong scientific and technological team can help banks respond timely in market competition and effectively realize the overall management including development goals, development planning, system integration and skill support. International banks possess a relatively mature management mode for scientific and technical personnel, in the field of which China's banking industry has some shortcomings, and a perfect technical management system hasn't been formed in China.

China's banking industry presently lacks the necessary cognition of differences, such as the organic combination of science and technology and banking business, the position and role of scientific and technical personnel, the special nature of scientific and technical personnel's labor and the differences in scientific and technological management. Because of unclear cognition and the lack of incentive system for scientific and technological talents, there is a lack of stability of the bank's scientific and technological talents, and a loss of related talents. It also affects the confidentiality and sustainability of banking system development. To develop steadily, banking industry needs to build a team of core software developers and technical management talents who are proficient in banking business and familiar with the characteristics of banking business processing and management. Therefore, it is necessary to adjust the structure of scientific and technological talents to change the present management mode of China's banking industry. Exploring and developing the core products of banks has become the pivot that the banking industry must pay attention to ${ }^{[3]}$.

\subsection{To strengthen the training on science and technology and supporting management of the banking industry}

Information technology has been widely applied in the whole business of banks at present. Effective use of the potential of information technology requires bank staff to master and apply it effectively. If the staff are not familiar with it or apply it properly, the application of information technology in banking will be affected and its advantages will not be brought into play. Therefore, it is necessary to strengthen the training of information skills for all employees in the banking industry. Combining with implementing supporting management of the business system, the safe operation and technical benefits of the banking system can be guaranteed. Supported by scientific management, information technology can give full play to its potential multiplier effect. Otherwise, it may cause multiple wastes of manpower, material resources and financial resources. With the development of information technology, the scientific and technological level of banking managers not only sets an example, but their scientific and technological application level and ability to manage a large amount of information and data to a great extent affect the scientific rationalization of management and decisions.

\subsection{Construction and development of financial computerizing}

Financial industry needs to perfect the management system of financial computerizing in order to advance towards the modern scientific and technological level. And it is necessary to cultivate innovative professional and technical personnel to realize financial technological innovation. Colleges and universities in China should combine with the reality of society and attach importance to the cultivation of students' practical ability. While enriching students' knowledge of financial theory, they should also encourage students to participate in internships in financial institutions, so that they can be familiar with work as soon as possible after graduation. Furthermore, students should learn the knowledge of financial science and technology actively and independently in internships, so as to fully grasp the technical skills of financial computerizing.

In addition, China should carry out macro-control on the construction and development of financial computerizing, and make a reasonable plan to enable financial computerizing to achieve network information sharing, so that the advantages of financial computerizing can be fully played and steady improvement of economic benefits can be achieved. Meanwhile, the overall planning should be full of assessment and prevention awareness of financial risks, combining with enhancing the core literacy ability of financial practitioners. 
To ensure the healthy and standard construction of financial computerization, effective supervision of the electronic financial business is needed. Hence, the relevant state departments need to further improve the laws and regulations related to the financial industry, and implement the supervision system to promote the smooth development of financial computerizing at the legal management level. Those who make use of financial computerizing to commit a crime must be severely punished, and strict supervision of financial computerizing should be carried out to prevent loopholes in any link, purifying the development environment of financial computerizing and giving full play to the efficiency of fintech management.

\section{Conclusion}

To sum up, both the construction of financial computerizing and fintech management are important components of financial technology work. Only the sound construction of financial computerizing can ensure the effective management. Therefore, the two should develop together to jointly promote the development and construction of national economy.

\section{References}

1. Scheubel B, Stracca L. What do we know about the global financial safety net? A new comprehensive data set. Journal of International Money and Finance 2019; 99.

2. Chu LK. The effects of financial development on economic sophistication: evidence from panel data. Applied Economics Letters 2019; 27(3): 1-4.

3. Chen Y, Hu J, Zhang W. Too connected to fail? Evidence from a Chinese financial risk spillover network. China \&World Economy 2020; 28(6): 78-100. 